\title{
Impact of Demutualization on Market Quality
}

\author{
Farman Ali $^{1^{*}}$ Man Wang ${ }^{2} \quad$ Imran Ali $^{3} \quad$ Syed Tauseef Ali \\ 1.School of Accounting, Dongbei University of Finance and Economics, China \\ 2.School of Accounting, Dongbei University of Finance and Economics, Internal Control Research Center in \\ China \\ 3.Department of Business Studies, Pakistan Institute of Developmental Economics, Pakistan
}

\begin{abstract}
The literature on market quality has focused on different perspectives but has overlooked its relationship with governance structure. This study analyzes the impact of a significant change in governance structure; that is demutualization, on market quality. We investigated one hundred thirty-seven non-financial firms listed on Demutualized Pakistan Stock Exchange and found that transaction cost has reduced by demutualization. We used two different proxies for transaction costs such as Thompson and Waller (1986) and Roll (1984) spread. We found that demutualization has a negative and significant impact on both proxies of the transaction cost. We conclude that demutualization has reduced the transaction cost and has improved market quality.
\end{abstract}

Keywords: Demutualization, Governance Structure, Transaction Cost, Market Quality

DOI: $10.7176 / \mathrm{EJBM} / 11-28-12$

Publication date:October $31^{\text {st }} 2019$

\section{Introduction}

Stock exchange demutualization, which is a major change in the governance structure, started in 1993 when the first exchange was demutualized. Since its inception, many of the stock exchanges have demutualized and had changed its governance structure from mutual to demutualize. Demutualization is the process of transforming a mutual organization owned by the member to a corporation owned by investors (Elliot, 2002). The traditional mutual exchanges operated as non-profit entities while the demutualized exchanges operate as for-profit corporations. Demutualization has resulted in the separation of ownership. Investors do not need to participate in the daily activities of the exchange. They have to provide the capital and enjoy the profit and voting rights. Investors try to invest in companies that are flexible enough to respond to the business environment changes and can produce a profit. The objective of both management and shareholder is to maximize the profit. Therefore, the company decisions should be in favour of both the management and investors (Hughes and Zargar, 2006).

Global competition has changed the governance structure of stock exchanges and has improved the performance and efficiency (Khan and Vieito, 2012; Slimane, 2012). This change has resulted in an increase in competition among exchanges for cross-listing and cross-trading in order to get benefit from both short-term and long-term efficiency (Werner and Kleidon, 1996; Kokkoris and Olivares-Caminal, 2008). Despite the development of the economy as a whole, demutualization also helps to develop the financial markets (Dorodnykh, 2014). Demutualization has increased the market share, trading volume and has reduced the bid-ask spread (Slimane, 2012). In the short run, demutualized stock exchanges may lose efficiency, but in the long run, they operate efficiently (Srinivasan, 2011). Demutualization has caused an increase in the profitability and efficiency of the exchanges (Padilla-Angulo \& Ben Slimane, 2018; Slimane \& Angulo, 2018).

The literature on demutualization has focused on the efficiency issues, welfare issues, or the profitability of the exchanges. There is a need to find the impact of demutualization on market performance in terms of quality and transaction cost. Prior literature is also confined to developed countries such as the USA and stock exchanges of Europe (Arnold et al., 1999; Khan and Vieito, 2012; Nielsson, 2009). There is a lack of studies in the emerging economies like Pakistan. This study is carried out to find whether demutualization of Pakistan Stock Exchange (PSX) has improved the quality of stock exchange, which is measured through transaction cost.

\section{Literature Review}

Changing in the ownership structure means that the organization is changing its strategy to cope with certain environmental changes. Stock exchanges change their ownership structure to cope with certain environmental changes such as globalization, global competition, and advancement in technology. Stock exchanges have been demutualized because the mutual structure failed to offer flexibility and finance needed to react to the current competitive environment (Serifsoy, 2008). For-profit investors run for-profit exchanges expecting to give better financing, help in making flexible decisions mechanism, and to expand new businesses (Aggarwal, 2002).

Advancement in telecommunication technologies and the growth of the internet and wireless networks are radically altering the structure and nature of financial services. Advancement of the internet and other such technologies have developed new and different means for organizations to provide their financial services (Claessens, Glaessner, \& Klingebiel, 2002). New technologies have been entered in the trading system, and now 
it is not confined to a certain geographical area or a physical location. Due to the development of Alternative Trading Systems (ATS) and Electronic Communication Networks (ECNs) exchanges are now not confined to provide the services of trade execution, signalling and other activities (Akhtar, 2002). ATS and ECNs are supported by high hardware capacity, software packages and other internet facilities. These have brought efficiency and effectiveness in the matching of buy/sell orders at low transaction cost. According to Galper (2001), advancement in technology has changed the landscape, enabled exchanges to overcome geographical boundaries, and has reduced the intermediary role of exchange members. This means investors are now not bound in their trading activities to such limitations like trading time and geographical location.

Stock exchanges are also facing a change in the competitive environment for the last two decades (Otchere \& Abou-Zied, (2008). Technological change has raised new competitors like ECNs, which compelled exchanges to change their structure. With changes in the competitive environment, the traditional mutual structure of stock exchanges becomes less attractive. The relationship between customer and exchange has changed to seek better services and liquidity. Interests of the members become deviating, and the benefits of the mutual structure were reduced. Another issue with the mutual structure is that of its ability to raise capital. The cost of organizing a cooperative is greater than its benefits (Mendiola \& O'Hara, 2003). It was tough for the old-style mutual exchanges to react to such competition. Due to these problems, some members of stock exchanges analyzed the need to introduce an electronic auction system. They analyzed that change in the corporate governance structure is essential. Therefore, they exerted pressure on members of stock exchanges and enforced them to accept the demutualization.

Demutualized exchanges are expected to act more rapidly to the environmental changes (Angel, 2003). Demutualized exchange gives greater independence because it facilitates trading and ownership privilege of its members. The management of a demutualized exchange takes actions which are in the best interest of its members and shareholders. Now the interest of both the shareholders and stock exchange are the same because both are willing to maximize profit. Demutualized exchanges will be more transparent because these are accountable to shareholders not only in bottom-line decisions but also in new issues related to corporate governance (Jordan \& Hughes, 2007).

Prior literature has focused on the liquidity, efficiency and profitability of the stock exchange. Nielsson (2009) analyzed the case of Euronext and reported that the merger had improved the liquidity. Hart and Moore (1996) stated that the efficiency of stock exchanges has enhanced after demutualization. Schmiedel (2001) and Schmiedel (2002) also reported a positive influence of demutualization on efficiency. Demutualization has also resulted in an increase in the financial performance of stock exchanges (Cybo-Ottone, Di Noia, \& Murgia, 2000; Aggarwal, 2002: Aggarwal \& Dahiya, 2006; Azzam, 2010). Krishnamurti, Sequeira, and Fangjian (2003) compared the market quality of National and Bombay stock exchanges and found that the market quality is improved by demutualization. Padilla-Angulo and Ben Slimane (2018) reported that financial performance is improved with the demutualization. They also stated that this relationship is moderated by corporate governance. Slimane and Angulo (2018) argued that the long term performance of exchange has improved after demutualization while they found no evidence of improvement in the short term performance.

This study contributes to the literature by finding the impact of demutualization on transaction cost in an emerging market context.

\subsection{Market Quality}

There is no single measure in the literature that quantifies the market quality. Researchers compare the market quality based on several measures such as volatility, informational efficiency, and liquidity. Market quality can also be measured through transaction cost (Krishnamurti, Sequeira, \& Fangjian, 2003). Transaction cost can be implicit, also known as execution cost, or implicit. Execution cost (implicit) can be calculated by subtracting the transaction price from the benchmark price. The execution cost is difficult to measure because it cannot be directly observed. Therefore, researchers have defined the execution cost in different ways and have given their own measures for it (e.g., Hasbrouck, 1993; Roll, 1984; Thompson \&Waller, 1986; Chan \& Lakonishok, 1993). Various measures are available to measure transaction cost. The most dominant measures of transaction cost are the effective bid-ask and quoted bid-ask spread. Transactions are executed on the quoted bid and ask prices when there is a pure dealership in the market. To measure transaction cost based on the quoted bid-ask spread, appropriate measures should be taken (Barclay et al., 1999; Huang \& Stoll, 1996). However, in some markets, there is high frequency trading. In such markets, trading occurs between the spread. This will overstate the investors' trading cost. This will result in the formation of effective spread. Effective spread is the difference between the selling and buying prices by dealer at the current and previous time, respectively. It is an appropriate measure of transaction cost (Roll, 1984).

This study uses two different measure of transaction cost, that is, Thompson and Waller (1986) and Roll (1984) spread. 


\subsection{Hypothesis Development}

Transaction cost is crucial because it affects the liquidity of the market. If the transaction cost is higher, it will be difficult for investors to buy and sell securities quickly. Transaction cost leads to higher market volatility (Hau, 2006). Amihud and Mendelson (1986) argued that when the bid-ask spread is higher, then investors will demand higher returns to compensate for the risk and higher trading cost.

Demutualization has resulted in increased liquidity (Neilson, 2009) due to which the number of market participants has increased. This increase in the number of the market participant may lead to a reduction in the transaction cost (Krishnamurti, Sequeira, \& Fangjian, 2003). Therefore, we hypothesize that demutualization has reduced the transaction cost and has improved the market quality.

\section{Data}

This study used unbalanced panel data that is composed of 137 non-financial firms listed on Pakistan Stock exchange for the period of 2005 to 2017. Data is obtained from different sources. To calculate the transaction cost, which is our dependent variable, we used daily prices. Data of stock prices are obtained from the website khistock (www.khistocks.com), which provides data related to the Pakistani financial market. The dependent variable of the study is the demutualization of PSX. As PSX is demutualized in 2012, we use a dummy variable which takes 1 value after demutualization and 0 otherwise. We exclude 2012 from our sample, which is the year of demutualization.

We also controlled for various firm-specific and macroeconomic variables that literature suggests can affect transaction cost. We controlled for profitability, size, leverage, and return volatility. Data of these variables are obtained from the financial statements of the firms. We also controlled for GDP and global financial crises. Data of GDP is obtained from the database of the World Bank while a dummy variable is used for the financial crises. All variables are defined and explained in table 1.

\subsection{Measuring Transaction Cost}

In this study, we used two different proxies for transaction cost, which are Thompson and Waller (1986) and Roll (1984) spread. Both of these models are based on the actual price changes. They are explained in the next section.

\section{Table 1. Definition of Variables}

\begin{tabular}{|c|c|c|}
\hline \multirow[b]{2}{*}{$\begin{array}{l}\text { Notation } \\
\text { Panel 1: } \text { Dependent } \\
\text { Variable (Transaction } \\
\text { Cost) }\end{array}$} & Name of variable & Explanation \\
\hline & & \\
\hline TW Spread & $\begin{array}{l}\text { Thompson and Waller } \\
\text { Spread }\end{array}$ & $\begin{array}{l}\text { It is the bid-ask spread calculated through Thompson } \\
\text { and Waller (1986) model. }\end{array}$ \\
\hline Roll Spread & Roll Spread & $\begin{array}{l}\text { It is the bid-ask spread calculated through the Roll } \\
\text { (1984) model. }\end{array}$ \\
\hline $\begin{array}{l}\text { Panel 2: Independent } \\
\text { Variable }\end{array}$ & & \\
\hline Demut & Demutualization & $\begin{array}{l}\text { It is change in the governance structure of stock } \\
\text { exchange. It is a dummy variable that takes } 0 \text { before } \\
\text { demutualization year and } 1 \text { otherwise. The year of } \\
\text { demutualization is } 2012 \text { in our case. }\end{array}$ \\
\hline $\begin{array}{l}\text { Panel 3: Control } \\
\text { Variables }\end{array}$ & & \\
\hline ROA & Return of Assets & Net income divided by total assets \\
\hline Size & Firm Size & $\begin{array}{l}\text { Market capitalization is used as size of the firm. It is } \\
\text { calculated as total number of shares times price per } \\
\text { share. }\end{array}$ \\
\hline Leverage & Leverage & It is calculated as total liabilities over total assets. \\
\hline Return_Volatility & Volatility of Returns & $\begin{array}{l}\text { Calculated by taking standard deviation of the stock } \\
\text { returns. }\end{array}$ \\
\hline GDP & Gross Domestic Product & Natural log on the GDP. \\
\hline Financial_Crisis & $\begin{array}{l}\text { Dummy variable for } \\
\text { Global financial crisis of } \\
2008\end{array}$ & $\begin{array}{l}\text { Dummy variable that takes } 0 \text { before crisis and } 1 \\
\text { otherwise }\end{array}$ \\
\hline
\end{tabular}

Note: This table provides an explanation of all the variables used in the study. Panel 1 explains the dependent variables of the study. Panel 2 explain the independent variable, while panel 3 explains the control variables of the study. 


\subsection{Thompson and Waller (1986) Spread}

Thompson and Waller spread is based on the absolute price changes. They were the pioneers to give the idea of calculating the bid-ask spreads through absolute price changes. The price change can be expressed as

$$
\Delta P_{t}=\frac{S}{2} I_{t}+\Delta m_{t}
$$

Where $\Delta P_{t}$ is the price change at time t. S denotes the spread. $I_{t}$ is an indicator variable. It takes value of -2 if sell follows a buy order, and takes 2 if a buy follows a sell order, and takes 0 otherwise. The formula for estimating the Thompson and Waller spread is,

$$
T W \text { Spread }=\frac{1}{T} \sum_{t=1}^{T}\left|\Delta P_{t}\right|
$$

Where $\mathrm{P}$ is the stock prices, and $\Delta P$ is the price changes. We take absolute of the price changes to find the absolute price changes.

\subsection{Roll (1984) Spread}

Roll (1984) give a model to measure transaction cost. He assumes that the market is efficient and that the actual prices follow a random walk. Roll spread can be calculated as,

$$
\text { Roll Spread }=2 \sqrt{-\operatorname{Cov}\left(\Delta P_{t}, \Delta P_{t-1}\right)}
$$

Where $\operatorname{Cov}\left(\Delta P_{t}, \Delta P_{t-1}\right)$ is the auto covariance of price changes and its lag value.

\section{Methodology}

To find the impact of demutualization on transaction cost, we estimated two different models. These models used different proxies for transaction cost. The first model uses Thompson and Waller (1986) spread as a proxy for transaction cost. To test whether transaction cost is reduced by demutualization, we estimated the following model,

TW Spread $i t=\alpha+\beta_{1}$ Demut $+\beta_{2}$ ROA $_{i t}+\beta_{3}$ Size $_{i t}+\beta_{4}$ Leverage $_{i t}+\beta_{5}$ Return_volatility $_{i t}+\beta_{6} G D P$

$+\beta_{7}$ Financial_Crises + Industry ${ }_{i}+$ Year $_{t}+\varepsilon_{i t}$

Where TW spread is Thompson and Waller spread. Demut is demutualization, ROA is the return on assets, size is the firm size, leverage is the leverage ratio of the firm, Return_volatility is the volatility of stock returns, GDP is the gross domestic product, Financial_Crises is the global financial crises of 2008, Industry is the dummy variable for each industry, and Year is the dummy variable for each year. $\varepsilon$ is the error term while i stands for the ith firm and $t$ stands for time. Hausman (1978) specification test is used to choose between fixed and random effect model.

The second proxy for transaction cost used in this study is the Roll (1984) spread. To test whether Roll spread is reduced after demutualization, we estimated the following model,

$$
\begin{aligned}
& \text { Roll Spread }_{i t}= \alpha+\beta_{1} \text { Demut }+\beta_{2} \text { ROA }_{i t}+\beta_{3} \text { Size }_{i t}+\beta_{4} \text { Leverage }_{i t}+\beta_{5} \text { Return_volatility }_{i t}+\beta_{6} G D P \\
&+\beta_{7} \text { Financial_Crises } \text { Industry } \\
& \text { Indear }_{t}+\varepsilon_{i t}
\end{aligned}
$$

Where Roll Spread is Roll (1984) spread. Demut is demutualization, ROA is the return on assets, size is the firm size, leverage is the leverage ratio of the firm, Return volatility is the volatility of stock returns, GDP is the gross domestic product, Financial_Crises is the global financial crises of 2008, Industry is the dummy variable for each industry, and Year is the dummy variable for each year. $\varepsilon$ is the error term while $\mathrm{i}$ stands for the ith firm and t stands for time.

\section{Empirical Results}

\subsection{Descriptive Statistics}

Before estimating our models, we give descriptive statistics of the dependent and other variables used in the study. We do not include two variables that are demutualization and financial crises because they are dummy variables. Table 2 reports the descriptive statistics of the data. Table 2 shows that the mean value of TW Spread is 10.262 and has a standard deviation (SD) of .976. This means that the variation in the Thompson Spread is very small. Table 2 also shows that there is not a very large difference in the minimum and maximum values of the Thompson spread. Comparatively, Roll spread has a higher variation as it has an SD of 249.059. Table 2 also shows that the min value of Roll spread is 0 , while the maximum value is 2852.317 , which means that there is a large difference in the values. The ROA shows moderate variation as its SD is 13.103 and also has a moderate difference in the minimum and maximum values. Size has a mean value of 22.907 and SD of 1.506, which means that there is low variation in the data. The minimum and maximum value of size also show a small difference. Leverage also shows a small variation as the SD is 0.299 . The minimum value of leverage is 0.006 , and the maximum value is 3.318 , which also show a small difference between the lowest and highest values. Return volatility has the mean value 3.377 and SD 1.758, which suggest that the variation is low in the data. Finally, GDP has a mean value of 16.569 and SD of 0.497 , which also suggest a low variation is the data. Table 2 shows that there are no extreme values for all variables in the data. 
Table 2. Descriptive Statistics

\begin{tabular}{lrrrrr}
\hline Variable & Obs & Mean & Std.Dev. & Min & Max \\
\hline TW Spread & 1616 & 10.262 & .976 & 5.368 & 13.926 \\
Roll Spread & 1188 & 141.716 & 249.059 & 0 & 2852.317 \\
ROA & 1338 & 6.981 & 13.103 & -163.28 & 67.96 \\
Size & 1338 & 22.907 & 1.506 & 18.174 & 27.165 \\
Leverage & 1336 & .52 & .299 & .006 & 3.318 \\
Return_Volatility & 1761 & 3.377 & 1.758 & .849 & 7.599 \\
GDP & 1761 & 16.569 & .487 & 15.72 & 17.217 \\
\hline
\end{tabular}

Note: This table reports the descriptive statistics of the data. Two proxies of depended variables are included in the table, that is TW Spread and Roll Spread. Demutualization and financial crises are dummy variables and are excluded from the table. All other variables are controlled variables. Obs is the number of observations; Mean is the mean value, Std.Dev is the standard deviation, Min is the minimum value, and Max is the maximum value. The sample period is from 2005 to 2017.

\subsection{Regression Results}

Before estimating the models to find the impact of demutualization on transaction cost, we find whether the FE or RE model is appropriate. We make the model selection decision based on the Hausman (1978) test. If this test is significant, then we choose FE model, otherwise, we choose RE model. Table 3 reports the results of the Hausman test, which suggest that FE models is more appropriate.

\section{Table 3. Hausman Test}

\begin{tabular}{lr}
\hline & Coef. \\
\hline Chi-square test value & 22.887 \\
P-value & .002 \\
\hline
\end{tabular}

Note: This table reports Hausman test results. The table provides the Chi-square statistics and its p-value.

Table 4 : Regression results

\begin{tabular}{lcc}
\hline & $(1)$ & $(2)$ \\
& TW_Spread & $-609.022^{*}$ \\
Demut & $-1.480^{* * *}$ & $(315.094)$ \\
& $(0.228)$ & $1.428^{* *}$ \\
ROA & -0.000 & $(0.644)$ \\
Size & $(0.000)$ & $63.620^{* * *}$ \\
& 0.010 & $(18.277)$ \\
Leverage & $(0.014)$ & -45.166 \\
& 0.035 & $(36.441)$ \\
Return_Volatility & $(0.031)$ & 6.406 \\
& $-0.894 * *$ & $(26.408)$ \\
GDP & $(0.089)$ & $-676.602 * *$ \\
& $-3.008 * * *$ & $(331.593)$ \\
Financial_Crisis & $(0.316)$ & 73.959 \\
& $0.894 * * *$ & $(101.121)$ \\
cons & $(0.197)$ & $-12260.438^{* *}$ \\
Obs. & $63.121 * * *$ & $(5432.269)$ \\
R-squared & $(5.448)$ & 786 \\
Industry Dummy & 1122 & 0.238 \\
Year Dummy & 0.829 & Yes \\
\hline
\end{tabular}

Note: This table reports the results of the regression analysis. Column 1 reports the results of the equation with Thompson and Waller spread as the dependent variable. Column 2 reports the results of the equation with Roll spread as the dependent variable. Definitions of all variables are given in Table 1. Standard errors are given in parenthesis. $* * *, * *$, and $*$ shows the significance at 10 per cent, 5 per cent, and 1 per cent level of significance, respectively.

Table 4 reports the results of the two estimated models. Two regressions are run to find the impact of demutualization on transaction cost. The $\mathrm{R}^{2}$ for model 1 and model 2 are 0.829 and 0.238 , respectively. Results show that the coefficient of demutualization is negative and significant for both models controlling for firmspecific variables, macroeconomic variables, industry effect, and year effect. These results suggest that transaction 
cost has significantly reduced after demutualization. The reason for this decrease in transaction cost and improved market quality is the change in the governance structure of the stock exchange. Domowitz and Steil (1999) argued that due to better governance, demutualized exchanges perform better in terms of investor protection, regulation, transparency, internal control system, and use of technology. More and more investors are attracted due to this improved governance and better protection. Moreover, demutualized exchanges provide easy access to remote investors for trading which boost up the trading activity and result in the reduction of the transaction cost. These results are consistent with Krishnamurti, Sequeira, and Fangjian (2003).

Table 4 report that size has no significant effect on transaction cost in model 1, while it shows a positive and significant impact of size on transaction cost in model 2 . These results suggest that transaction cost increases with an increase in the firm size. The coefficient of leverage is insignificant in case of both models. This suggests that leverage has no influence on transaction cost in our case. Stock return volatility has a negative and significant impact on transaction cost in case of model 1. This means that transaction cost decrease with increase in stock return volatility. Table 4 also shows that the coefficient of GDP is negative and significant for both models. An increase in GDP causes a decrease in the transaction cost. Finally, the coefficient of financial crises is positive and significant in model 1 but is insignificant in model 2.

Summing up, we explore whether transaction cost has reduced after demutualization and found that it has significantly reduced. Results are significant for both of the models. Demutualized stock exchange performs better than mutual. Due to improved governance and efficiency, it attracts more investors and has increased the trading activity. This has reduced that bid-ask spread which results in low transaction cost and higher market quality.

\section{Conclusions}

Stock exchange provides the trading services to investors. Previous literature has focused to analyze the market quality from different perspectives. The relationship between demutualization and transaction cost is overlooked by researchers. Domowitz and Steil (1999) argued that the member of mutual exchanges oppose the change in governance structure because it will eliminate their intermediation role. However, the shareholders of the demutualized stock exchange support this change because this enhances the value of the firm. Taking Pakistan Stock Exchange as a case, which has demutualized in 2012, we found that transaction cost has reduced after demutualization and hence market quality is improved. These results are consistent with prior literature.

This study has implications for the emerging market where the regulators have no control on the monopolists. Demutualization enhances the competition, which will reduce the influence of the monopolists. Demutualized stock exchanges also use the latest technology which helps to eliminate the need to go to the trading floor. This enhances the trading activity and hence reduces the transaction cost. In short, demutualization causes an improvement in the market quality in emerging markets.

\section{References}

Aggarwal, R. (2002). Demutualization and corporate governance of stock exchanges.

Aggarwal, R., \& Dahiya, S. (2006). Demutualization and public offerings of financial exchanges. Journal of Applied Corporate Finance, 18(3), 96-106.

Akhtar, S. (2002). Demutualization of stock exchanges: problems, solutions and case studies. Asian Development Bank.

Amihud, Y., \& Mendelson, H. (1986). Liquidity and stock returns. Financial Analysts Journal, 42(3), 43-48.

Angel, J. J. (2003). Discussion of "Stock exchange governance and market quality" by Krishnamurti, Sequeira, and Fangjian. Journal of banking \& finance, 27(9), 1879-1881.

Arnold, T., Hersch, P., Mulherin, J. H., \& Netter, J. (1999). Merging markets. The Journal of Finance, 54(3), 1083-1107.

Azzam, I. (2010). Stock exchange demutualization and performance. Global Finance Journal, 21(2), 211-222.

Barclay, M. J., Christie, W. G., Harris, J. H., Kandel, E., \& Schultz, P. H. (1999). Effects of market reform on the trading costs and depths of Nasdaq stocks. The Journal of Finance, 54(1), 1-34.

Ben Slimane, F. (2012). Stock exchange consolidation and return volatility. Managerial Finance, 38(6), 606-627.

Chan, L. K., \& Lakonishok, J. (1993). Institutional trades and intraday stock price behavior. Journal of Financial Economics, 33(2), 173-199.

Claessens, S., Glaessner, T., \& Klingebiel, D. (2002). Electronic finance: reshaping the financial landscape around the world. Journal of Financial Services Research, 22(1-2), 29-61.

Cybo-Ottone, A., Di Noia, C., \& Murgia, M. (2000). Recent development in the structure of securities markets. Brookings-Wharton papers on financial services, 2000(1), 223-273.

Domowitz, I., \& Steil, B. (1999). Automation, trading costs, and the structure of the trading services industry. Brookings-Wharton papers on financial services, 1999, 33-92.

Dorodnykh, E. (2014). Determinants of stock exchange integration: evidence in worldwide perspective. Journal of Economic Studies, 41(2), 292-316. 
Elliot, J. (2002). Demutualization of Securities Exchanges: A regulatory Perspective,

IMF working Paper, WP/02/119.

Galper, J. (2001). Three business models for the stock exchange industry. The Journal of Investing, 10(1), 70-78.

Hart, O., \& Moore, J. (1996). The governance of exchanges: members' cooperatives versus outside ownership. Oxford review of economic policy, 12(4), 53-69.

Hasbrouck, J. (1993). Assessing the quality of a security market: A new approach to transaction-cost measurement. The Review of Financial Studies, 6(1), 191-212.

Hau, H. (2006). The role of transaction costs for financial volatility: Evidence from the Paris Bourse. Journal of the European Economic Association, 4(4), 862-890.

Hausman, J. A. (1978). Specification tests in econometrics. Econometrica: Journal of the econometric society, 1251-1271.

Huang, R. D., \& Stoll, H. R. (1996). Competitive trading of NYSE listed stocks: Measurement and interpretation of trading costs. Financial Markets Institutions and Instruments, 5.

Hughes, P. S., \& Zargar, E. (2006). Exchange demutualization. Paper presented at the APEC Financial Regulators Training Initiative Regional Seminar Demutualization of Exchange, Manila.

Jordan, C., \& Hughes, P. (2007). Which way for market institutions: The fundamental question of self-regulation. Berkeley Bus. LJ, 4, 205.

Khan, W., \& Vieito, J. P. (2012). Stock exchange mergers and weak form of market efficiency: The case of Euronext Lisbon. International Review of Economics \& Finance, 22(1), 173-189.

Krishnamurti, C., Sequeira, J. M., \& Fangjian, F. (2003). Stock exchange governance and market quality. Journal of banking \& finance, 27(9), 1859-1878.

Kokkoris, I., \& Olivares-Caminal, R. (2008). Lessons from the recent stock exchange merger activity. Journal of Competition Law and Economics, 4(3), 837-869.

Padilla-Angulo, L., \& Ben Slimane, F. (2018). Board restructuring and successful demutualization: the stock exchanges. Journal of Organizational Change Management, 31(3), 598-618.

Nielsson, U. (2009). Stock exchange merger and liquidity: The case of Euronext. Journal of Financial Markets, $12(2), 229-267$

Roll, R. (1984). A simple implicit measure of the effective bid-ask spread in an efficient market. The Journal of finance, 39(4), 1127-1139.

Serifsoy, B. (2008). Demutualization, outsider ownership, and stock exchange performance: empirical evidence. Economics of Governance, 9(4), 305.

O'Hara, M., \& Mendiola, A. M. (2003). Taking stock in stock markets: the changing governance of exchanges. Available at SSRN 431580

Otchere, I., \& Abou-Zied, K. (2008). Stock exchange demutualization, self-listing and performance: The case of the Australian Stock Exchange. Journal of banking \& finance, 32(4), 512-525.

Schmiedel, H. (2001). Technological development and concentration of stock exchanges in Europe.

Schmiedel, H. (2002). Total factor productivity growth in European stock exchanges: A non-parametric frontier approach.

Slimane, F. B., \& Angulo, L. P. (2018). Strategic change and corporate governance: Evidence from the stock exchange industry. Journal of Business Research.

Srinivasan, P. (2011). Stock Market Efficiency and Common Stochastic Trends: A Case of NSE and BSE. IUP Journal of Financial Risk Management, 8(2).

Thompson, S., \& Waller, M. (1986). The Execution Cost of Trading in Commodity Futures Markets.

Werner, I. M., \& Kleidon, A. W. (1996). UK and US trading of British cross-listed stocks: An intraday analysis of market integration. The Review of Financial Studies, 9(2), 619-664. 